\title{
A Method for Monitoring Antibodies against Staphylococcal DNases
}

\author{
By Steinar Høie and Roar Gudding \\ Department of Microbiology and Immunology, Norwegian College \\ of Veterinary Medicine and the National Veterinary Institute, Oslo, Norway.
}

\begin{abstract}
Heie, S. and R. Gudding: A method for monitoring antibodies against staphylococcal DNase. Acta vet. scand. 1990, 31, 223-226. - When small amounts of DNase produced by Staphylococcus aureus, S. intermedius or S. hyicus were added to Toluidine Blue DNA Agar (TDA), a medium for demonstration of staphylococcal antiDNases was produced. By applying this medium in microtitre plates, a test system for titration of staphylococcal antibodies in serum samples was developed. A colour change from blue to pink could be observed when the DNase was allowed to act, i.e. when no staphylococcal antiDNases were present in the samples. When serum with neutralizing antibodies were applied, no colour change developed. An end-point could easily be demonstrated in dilutions of the serum. A description of the method, including certain of its limitations is given.
\end{abstract}

antiDNases; Staphylococcus aureus; Staphylococcus intermedius; Staphylococcus hyicus.

\section{Introduction}

Production of a heat-stable DNase is a common characteristic of Staphylococcus aureus, $S$. intermedius and S. hyicus. As the enzyme is immunogenic and produced in large amounts by all or most strains, antibodies against these DNases (antiDNases) are demonstrated in serum and other biological fluids from man and animals infected with these organisms (Gudding 1980, Ness 1984, Hoie \& Fossum 1989, Hoie et al. 1989). Furthermore, the DNases of $S$. aureus, $S$. intermedius and $S$. hyicus are serologically different when tests for specific inhibition of the enzyme activities are applied (Gudding 1983).

Antibodies against the active sites of DNase have been demonstrated using a crosswiseinhibition test (Sandvik 1974), and agar diffusion tests (Gudding 1977, Ness 1984). These tests are based on the neutralization of the DNase activity, and visualized by colour changes in the Toluidine Blue DNA Agar (Lachica et al. 1971), which is a sub- strate showing the activity of DNA-hydrolyzing enzymes. However, for accurate titration of antiDNases in series of blood sera improved methods should be developed.

The objective of the present study was to develop a labour-saving, agar diffusion test for quantification of antibodies against staphylococcal DNases in microtitre plates. Special attention was given to factors which influenced the sensitivity and accuracy of the method.

\section{Material and methods}

Bacterial strains and sera

The following strains of Staphylococcus spp. were used for the production of $\mathrm{DNa}$ ses: S. aureus ATCC* 27543 and S. aureus $\mathrm{NVH}^{* *} 3610$ (goat mastitis origin), S. inter-

\footnotetext{
* American Type Culture Collection, Rockville, Maryland, USA.

** The culture collection at the Department of Microbiology and Immunology, Veterinary College of Norway, Oslo.
} 
medius NVH 3670 (dog origin), and S. hyicus ATCC 11249.

\section{Preparation of DNase}

Twenty $\mathrm{ml}$ of a suspension of bacterial strains in saline was transferred to a sterilized bag of dialysis membrane. The bag was placed in an Erlenmeyer flask with Heart Infusion Broth (Difco). After incubation at $37^{\circ} \mathrm{C}$ for $48 \mathrm{~h}$, the bacterial suspensions were centrifuged at $1560 \mathrm{~g}$ for $15 \mathrm{~min}$, heated over a boiling water bath for $15 \mathrm{~min}$, and preserved by the addition of merthiolate to a final dilution of $1: 10.000$. These solutions could be stored at $4^{\circ} \mathrm{C}$ for at least 6 months without any significant change in the DNase activity.

The DNase activity of the solutions was related to that of commercially available DNase*. The activity of this DNase was expressed in units, 1 unit being defined as the activity of enzyme producing $1.0 \mathrm{mmol} / \mathrm{l}$ of acid-soluble polynucleotides from native DNA per min at $\mathrm{pH} 8.8$ and a temperature of $37^{\circ} \mathrm{C}$. The activity of the DNases was measured by the turbidimetric method described by Erickson \& Deibel (1973) using DNA from Difco as substrate. Using the commercial DNase as reference, stock solutions of the DNases of the 4 staphylococcal strains were prepared.

\section{Preparation of antiDNase microtitre plates} The Toluidine Blue DNA Agar (TDA) was prepared as described by Lachica et al. (1971). The melted agar was placed in a water-bath at $56^{\circ} \mathrm{C}$ and the aliquots of the DNase solutions were added under constant stirring. The TDA with added DNase was filled into wells in F-shaped microtitre plates**. The plates were stored at $4^{\circ} \mathrm{C}$ for

\footnotetext{
* Sigma. No. N-3755. Micrococcal nuclease from Staphylococcus aureus. Foggi strain.

** Greiner Labortechnik.
}

maximum $4 \mathrm{~h}$ before serum dilutions were applied.

Approximately 50 test sera from man and various animals were used. Two-fold dilutions of the test sera were made in 0.05 mol/l Tris $\mathrm{HCl}$ buffer $\mathrm{pH} 9.0$, and aliquots of these dilutions were applied into the wells. The plates were preincubated for $18 \mathrm{~h}$ at $4^{\circ} \mathrm{C}$ and subsequently incubated at $37^{\circ} \mathrm{C}$ for $24 \mathrm{~h}$.

\section{Test procedure}

After the incubation period, the plates were inspected against a white background and with lighting from below. This examination was also performed after storing the plates for $24 \mathrm{~h}$ at $4^{\circ} \mathrm{C}$.

\section{Variable factors}

Composition of TDA. The Toluidine Blue DNA Agar was used as basic substrate. The following agar concentrations were tested: $0.25 \%, 0.50 \%, 0.75 \%, 1.00 \%$ and $1.25 \%$.

DNase activity. The DNase was added to TDA to give the following enzyme activity: $0.016,0.030,0.046,0.060$ and 0.076 units per $100 \mathrm{ml}$.

Volume of medium and serum. The following volumes of medium in the wells were tested: 50, 100, 150, 200 and $250 \mu \mathrm{l}$. The serum dilutions were added to the solid agar in 5 different volumes: $10,15,20,30$ and $40 \mu$.

\section{Results}

When microtitre plates with TDA containing DNase were incubated at $37^{\circ} \mathrm{C}$ for $24 \mathrm{~h}$ and then inspected against a white background with lighting from below, it was found that the original blue colour had changed to pink. No colour change occurred in wells with homologous antibodies, due to the inhibition of DNase activity by the antiDNases. When the antiDNases were serially 
diluted, an end-point could be determined, this indicating that the method could be used for antibody titrations. However, the sensitivity of the method and the distinctness of the end-point were influenced by various factors. The concentration of DNase could be varied considerably without altering the test results. The least amount of DNase producing an acceptable colour change, 0.046 units $/ 100 \mathrm{ml}$ TDA, was found suitable and therefore used throughout the study.

Agar concentrations of $0.50 \%$ or $0.75 \%$ were found to be the most appropriate, the former being preferred in this study. Lower agar concentrations did not result in acceptable colour change, while agar concentrations of $1 \%$ and higher made the determination of end-point more difficult.

The optimal volume of TDA medium in the wells of the microtitre plates was found to be $100 \mu \mathrm{l}$. Larger volumes of medium prevented the passage of light through the TDA, thus making the visualization of the endpoint less distinct. Volumes below $100 \mu \mathrm{l}$ made it difficult to cover the bottom of the wells properly. The most appropriate volume of serum or serum dilutions was found to be $20 \mu \mathrm{l}$. When larger volumes were used, the colour of the medium was influenced negatively, while smaller volumes did not properly cover the medium in the wells.

Overnight incubation was found to be optimal, though increasing the incubating time to $48 \mathrm{~h}$ did not influence the colour change. However, a shorter incubation period (less than $24 \mathrm{~h}$ ) gave a less distinct colour difference when the concentration of DNase was 0.046 units $/ 100 \mathrm{ml}$ TDA.

Microtitre plates stored at $4^{\circ} \mathrm{C}$ for $24 \mathrm{~h}$ after incubation at $37^{\circ} \mathrm{C}$ were easier to read due to better contrast between the colour indicating DNase activity and the original colour of the medium.

\section{Discussion}

The principle of this method for the detection of antibodies against staphylococcal DNases is based on the metachromatic properties of the Toluidine Blue DNA Agar. The use of microtitre plates allows the method to be used for quantitative examination of the antienzymes in serum. One advantage the method has is that it permits the use of both crude enzyme-containing material as well as untreated sera. Practice of the method is enhanced by the fact that the DNase solution and the medium used for the test are both stable, and can thus be easily stored.

Several factors are decisive for the sensitivity and the suitability of the method. The concentration of the DNase in the medium is of particular interest since it has to represent a compromise and satisfy two counteracting conditions, i.e. it has to be sufficiently high to give a distinct colour contrast, and yet at the same time it has to be sufficiently low to be neutralized by the presence of small amounts of antibodies. In the present study the plates were read manually. Automatic reading using an appropriate wavelength might be a feasible alternative. Another factor which will affect the sensitivity of the method is the length of time the microtitre plates are stored after the addition of enzyme. The increase in enzyme activity of $S$. aureus DNase when the temperature was increased $10^{\circ} \mathrm{C}$ has been found to be 2.16 $\left(Q_{10}\right)$ and the enzyme shows activity even at refrigerator temperature (Gudding 1977). The storage time should therefore be limited in order to maintain the sensitivity of the system.

Other factors may also influence the test. The toluidine blue preparations produced by various manufacturers may differ in dye content (Waller et al. 1985). In the present study the toluidine blue from Merck was 
used. Furthermore, agar, and not agarose, should be used to achieve a desired colour change (Hoie, unpublished).

The method has been used for examination of serum. This means that naturally occurring DNases in serum might constitute a source of interference. However, the concentration of these enzymes is low in serum from most animal species and their $\mathrm{pH}$ optima are lower than those of staphylococcal DNases (Gudding 1979).

The titres of antibodies against stapylococcal DNases in sera from different animals have been analyzed using this microtitre plate method (Høie \& Fossum 1989, Hoie et al. 1989). Compared with the agar diffusion test used by Ness (1984), the present method was found to be more specific (Hoie \& Fossum 1989).

\section{References}

Erickson A, Deibel RH: Turbidimetric assay of staphylococcal nuclease. Appl. Microbiol. 1973, 25, 337-341.

Gudding $R$ : An agar diffusion method for the determination of antibodies against Staphylococcus aureus nuclease. Acta vet. scand. 1977, 18, 480-493.

Gudding $R$ : DNases in milk and blood sera from different species. Acta vet. scand. 1979, 20, 404-416.

Gudding $R$ : Antibodies against staphylococcal and streptococcal nucleases in bovine blood serum and milk. Acta vet. scand. 1980, 21, 242-255.

Gudding $R$ : Differentiation of staphylococci on the basis of nuclease properties. J. clin. Microbiol. 1983, 18, 1098-1101.
Hoie S, Holstad G, Slettbakk T: Antibodies against Staphylococcus aureus DNase in goat serum. Acta vet. scand. 1990, 31, 253-254.

Hoie $S$, Fossum $K$ : Antibodies against staphylococcal DNases in serum from different animal species including man. J. clin. Microbiol. 1989 , to be published.

Lachica RVF, Genigeorgis C, Hoeprich PD: Metachromatic agar-diffusion methods for detecting staphylococcal nuclease activity. Appl. Microbiol. 1971, 25, 585-587.

Ness E: Patterns of antibodies to staphylococcal DNases in dog sera. J. clin. Microbiol. 1984, 20, 806-807.

Sandvik $O$ : The occurence of antibodies against staphylococcal deoxyribonucleases in blood sera from different species. Acta vet. scand. 1974, 15, 631-635.

Waller JR, Hodel SL, Nuti RN: Improvement of two toluidine blue O-mediated techniques for DNase detection. J. clin. Microbiol. 1985, 21, 195-199.

\section{Sammendrag}

En metode for undersøkelse av antistoffer mot stafylokokk-DNaser.

Ved å sette små mengder DNase produsert av Staphylococcus aureus, S. intermedius eller $S$. hyicus til toluidinblått-DNA-agar ble det laget et medium som kunne benyttes til påvisning av stafylokokk-antiDNase. Ved å benytte dette agarmediet i mikrotiterplater ble det utviklet et testsystem for titrering av antistoffer mot stafylokokk-DNase i serumprøver. I prøver uten antiDNaser skjedde det en fargeforandring fra blå til rosa på grunn av DNaseaktiviteten. Serumprøver med nøytraliserende antistoffer ga ingen fargeforandring. Metoden og enkelte begrensninger ved den er beskrevet.

(Received March 28, 1989; accepted October 3, 1989).

Reprints may be requested from: S. Høie, National Veterinary Institute, P. O. Box 8156, N-0033 Oslo 1, Norway. 